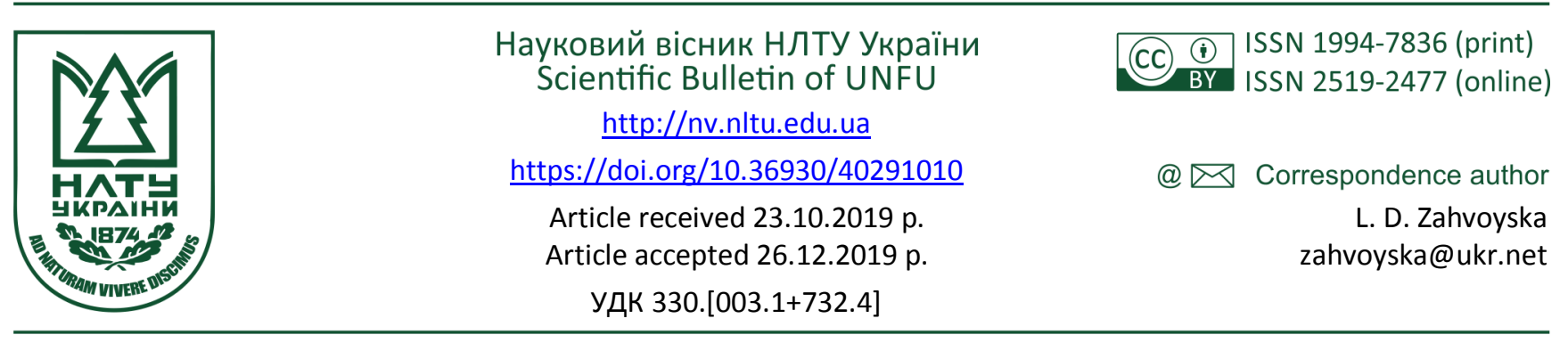

Ю. Ю. Туниця, Л. Р. Лиско, Л. Д. Загвойська, І. П. Соловій Національний лісотехнічний університет Украйни, м. Львів, Украӥна

\title{
СТАЛИЙ УНІВЕРСИТЕТ: МОДЕЛЬ СИСТЕМНОЇ ІНТЕГРАЦІЇ ПРИНЦИПІВ СТАЛОГО РОЗВИТКУ В УСІ СФЕРИ ДІЯЛЬНОСТІ
}

\begin{abstract}
Проаналізовано світоглядні та загальнометодологічні передумови екологізації освітньої діяльності університетів на основі концепції людського капіталу сталого розвитку. Обгрунтовано економічний дискурс освіти для сталого розвитку, який базується на системно-синергетичній парадигмі, а також окреслено сучасні тенденції розвитку систем освіти. Досліджено методологічні та дидактичні аспекти екологізації освітньої діяльності університетів на засадах компетентнісного підходу. Розкрито теоретичні та методичні особливості екологізації різних напрямів підготовки фахівців на основі концепції людського капіталу сталого розвитку. Розглянуто роль університетів у реалізації Стратегії СЕК ООН. Вивчено світовий досвід переходу університетів до сталості. На засадах підходу "всієї школи" проаналізовано ключові аспекти імплементації соціальної відповідальності університету. Обгрунтовано роль цього підходу у формуванні сучасного дискурсу освіти для сталого розвитку, який сприяє підвищенню іiі дієвості, викликає зміни у професійній і побутовій поведінці. З'ясовано передумови системної та цілісної інтеграції принципів сталості в усі сфери діяльності університетів. Особливу увагу звернено на досвід Національного лісотехнічного університету України як репрезентанта формування і втілення в життя моделі цілісної концепції екологізації вищої професійної освіти.
\end{abstract}

Ключові слова: освіта для сталого розвитку; екологізація освіти; людський капітал; компетентнісний підхід; сталий університет.

Вступ. Концепціiя сталого розвитку - глобальний виклик суспільній практиці XXI ст., який вимагає парадигмального переосмислення орієнтирів розвитку людства: відповідального ставлення до довкілля і природних ресурсів, розвитку економіки, освіти, культури. Інклюзивна та якісна освіта і заохочення до навчання впродовж усього життя стають одним із найвищих пріоритетів "Порядку денного 3 сталого розвитку до 2030 року", прийнятого на Саміті ООН 3 Розвитку (2015 р.) і "Платформи для дій "Освіта-2030"'", схваленої на 38-й сесії Генеральної конференції ЮНЕСКО (2015 p.).

Щодо цих світових тенденцій система освіти, іiі трансформація на засадах сталого розвитку набуває актуальності як науково-методична та організаиійно-уnравлінська проблема. Вона має міждисциплінарний характер і потребує залучення до її вирішення потенціалу різних наук. У Національному лісотехнічному університеті під керівництвом академіка Ю. Ю. Туниці утворився колектив науковців, більшість 3 яких проходили стажування у провідних університетах європейських країн і США з інтегруючою концепцією університетської освіти для сталого розвитку. Він дав змогу всесто- ронньо і кваліфіковано опрацьовувати різні аспекти досліджуваної проблеми та виробити адаптовані до українських реалій підходи. Було запропоновано нове бачення та оригінальні розробки щодо перспектив наукових досліджень цієї актуальної проблеми (Tunytsya, 2017).

Підходи до процесу підготовки фахівців для сталого розвитку випливають насамперед з методологічної характеристики самого феномену сталого розвитку. Результати дослідження перебувають в руслі інтенсивних пошуків засобів подолання глобальних проблем людства, які здійснює світове наукове співтовариство. Про це зокрема свідчить ювілейна доповідь Римського клубу "Come On! (укр. "приєднуйтесь до нас")" - "Kanimaлізм, недалекоглядність, населення та знищення плане$m u^{\prime \prime}$ (von Weizsaecker and Wijkman, 2018). Знаменно, що другу частину цієї доповіді автори розпочали з обговорення екологічної енцикліки папи Франциска (Laudato si, 2015), в якій системно діагностовано проблеми сучасності, з'ясовано витоки сучасного світогляду та запропоновано альтернативну філософію "нового Просвітництва", а також зроблений наголос на значенні світових релігій у розвитку турботи про планету як "Сniльний дім" (Laudato si, 2015).

Інформація про авторів:

Туниця Юрій Юрійович, д-р екон. наук, професор, академік НАН України, ректор. Email: nltu@ukr.net

Лиско Любомир Романович, канд. екон. наук, доцент, кафедра екологічної економіки. Email: lyubomyr.lysko@gmail.com

Загвойська Людмила Дмитрівна, канд. екон. наук, доцент, кафедра екологічної економіки. Email: zahvoyska@ukr.net; https://orcid.org/0000-0002-0028-4723

Соловій Ігор Павлович, д-р екон. наук, професор, кафедра екологічної економіки. Email: soloviy@yahoo.co.uk

Цитування за ДСту: Туниця Ю. Ю., Лиско Л. Р., Загвойська Л. Д., Соловій І. П. Сталий університет: модель системної інтеграції принципів сталого розвитку в усі сфери діяльності. Науковий вісник НЛтУ України. 2019, т. 29, № 10. С. 54-60.

Citation APA: Tunytsya, Yu. Yu., Lysko, L. R., Zahvoyska, L. D., \& Soloviy, I. P. (2019). Sustainable university: the model of systemic integration of sustainability priciples in all spheres of activity. Scientific Bulletin of UNFU, 29(10), 54-60. https://doi.org/10.36930/40291010 
У центрі світоглядної концепції авторів наукового проекту "Теоретико-методологічні засади екологізації освіти як чинника формування людського капіталу для сталого розвитку" (Zasady, 2017) перебуває людина, проблеми ї̈ гармонійного розвитку, яку системно описано на фундаментальних засадах цілісного гуманізму й екологізму. Науково-дослідна робота була спрямована на реалізацію зобов'язань, внесених на саміті $\mathrm{OOH}$ "Ріо+20" до реєстру від імені України під назвою: "Екологізація освіти: внесок України" (Greening of Education: Ukraine's Contribution, 2012).

Дослідження світоглядних і методологічних аспектів процесу підготовки фахівців для сталого розвитку опиралось на досягнення дидактики як теорії навчання. Цей аспект проблематики відобразив специфіку екологізації процесу підготовки фахівців різного професійного спрямування: у сфері природокористування та охорони довкілля, технічних, економічних, соціально-гуманітарних, мистецтва тощо. Для вирішення завдань дослідження використано новітню системно-синергетичну методологію наукового пізнання, яка дала змогу представити у взаємозв'язку основні поняття, необхідні для моделювання людини, природи, суспільства й економіки 3 позицій парадигми сталого розвитку як інтегрованого об'єкта наукової та освітньої діяльності.

3 метою апробації наших підходів була проведена міжнародна науково-методична конференція "Підготовка фахівців для сталого розвитку: досвід, проблеми, перспективи" (22-23 жовтня 2014 р.). Другу міжнародну науково-практичну конференцію "Екологізація освіти як чинник сталого розвитку суспільства" (Львів, жовтень 2017 р.) було спрямовано на пошук шляхів реалізації Стратегії сталого розвитку "Україна-2020", виконання рішення Колегії МОН України "Про екологізацію вищої освіти України з метою підготовки фахівців для сталого розвитку" (№10/5-4 від 25 листопада 2015 р.), а також актуальних вимог щодо підготовки фахівців для сталого розвитку, що містяться в документах Спеціального саміту ООН зі сталого розвитку (вересень 2015 р.), запропонованих ЮНЕСКО Рамок дій "Освіта-2030" (листопад 2015 р.), Паризької кліматичної угоди (грудень 2015), Закону України "Про освіту" (вересень 2017 p.).

У світовій науці впродовж останнього десятиліття виконувались інтенсивні дисциплінарні, міждисциплінарні і трансдисциплінарні дослідження за цим напрямом. Але досі, як влучно зауважив історик економічної науки, лауреат Нобелівської премії Джордж Стіглер, нові ідеї не призвели в цих дослідженнях до відмови від попередньої спадщини. Запропонована наукова парадигма сталого розвитку якраз повинна докорінно змінити об'єкт, предмет і методи наукових досліджень.

\section{Узагальнювальні результати досліджень:}

1. Світоглядні та загальнометодологічні передумови екологізації освітньої діяльності університетів на основі концепції людського капіталу сталого розвитку: ноосферна стратегія сталого розвитку людства і нова роль науки та освіти, світоглядна основа діяльності сучасних університетів, міждисциплінарний підхід до дослідження проблем формування людського капіталу та економічний дискурс освіти для сталого розвитку.
2. Методологічні та дидактичні аспекти екологізації освітньої діяльності університетів на засадах компетентнісного підходу: екологічні та економічні компетентності як підгрунтя для формування еколого-економічного мислення здобувачів вищої освіти, оцінювання рівня сформованості екологічної компетентності випускника ВНЗ як результату екологізації навчання, екологічні практики як засіб формування екологічної компетентності фахівця з вищою освітою, психологопедагогічні аспекти екологізації вищої освіти, теоретичні та методичні особливості екологізації різних напрямів підготовки фахівців на основі концепції людського капіталу сталого розвитку.

3. Системна та цілісна інтеграція принципів сталості в усі сфери діяльності: визначено методологічні та організаційні підстави соціальної відповідальності університету щодо сталого розвитку. Запропоновано структуру, етапи та умови іiі розвитку: від усвідомлення необхідності імплементації цілей і принципів сталого розвитку в усі аспекти діяльності університету, формування функціонального імперативу сталої діяльності до реалізації іiі в конкретних діях та взаємодії з іншими суб'єктами соціальної відповідальності суспільства. Обгрунтовано потребу моніторингової оцінки діяльності університету з позицій його відповідальності за досягнення цілей сталого розвитку та корегування діяльності в інтересах гармонізації взаємодії з суспільством та довкіллям на засадах сталості.

Виклад основного матеріалу. 3 аналізу видно, наскільки глибоко ресурсно-екологічні проблеми пов'язані 3 демографічними, економічними, соціально-політичними, соціокультурними реаліями сьогодення. Одне 3 важливих питань цього комплексу - роль потреб у соиіальному механізмі їх вирішення. Адже до проблем екологічного характеру найчастіше призводить надмірне виробництво, метою розширення якого $\epsilon$ саме задоволення невиправдано великих потреб. Їх необхідно обмежити рівнем розумних потреб, і ця вимога відразу ж логічно переходить до вчення В. Вернадського про ноосферу.

Як і в ювілейній доповіді Римського клубу (Weizsaecker and Wijkman 2018), наголошуємо на синергії між різними сферами життя, а також пошуку балансу:

- між людьми та природою - сталий розвиток і екологічна свідомість;

- між короткотерміновою та довготривалою перспективамu;

- між швидкістю і стабільністю - зміни і прогрес не повинні сприйматись як самоцінність;

- між індивідуальним i колективним - визнаючи значення особистої автономії - одного 3 найважливіших завоювань європейського Просвітництва, - яке в економіці означає, що держава (суспільство) повинно встановлювати правила для ринків, а не навпаки;

- між жінками та чоловіками, зокрема через перехід від моделей домінування до моделей партнерства та взаємної довіри;

- між рівністю та справедливою винагородою - від держави вимагається забезпечити механізми, що гарантує соціальну справедливість;

- між державою та релісією.

Новий соиіогуманістичний імператив майбутнього, якому немає альтернативи, спирається на розуміння людства як великої світової родини, а Землі - як Спільного дому. Як прогнозував визначний український фу- 
туролог і гуманіст член Римського клубу Б. Гаврилишин, "ще впродовж десятиліть людство мандруватиме до мети звивистими шляхами. Проте з часом ичі шляхи напевно зблизяться. Ми не можемо покинути нашу планету, ми не бажаємо ї̈ руйнації. Жодна частина людства не в змозі ї̈ привласнити. Нам варто пристосуватись до правил співжиття, якими будемо керуватись в умовах майбутнього єдиного світового ладу, нашої спільної долі" (Havrylyshyn, 1993).

ПРИРОДНЕ СЕРЕДОВИЩЕ

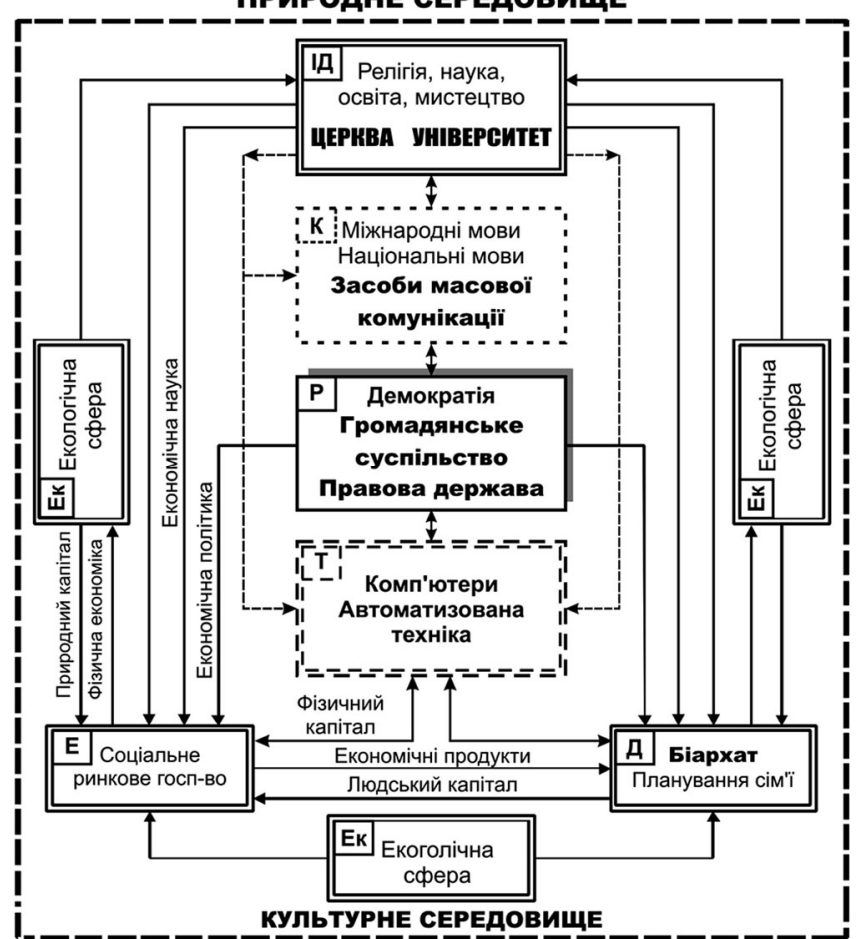

Рис. 1. Функціональна модель цивілізації сталого розвитку. Сфери функціонування: Д - демографічна; Е - економічна; ІД інформаційно-духовна; К - комунікаційна; Т - технічна; Ек екологічна; Р - регулятивна

Контури такого майбутнього єдиного світового ладу (або циивілізації сталого розвитку) змодельовано на рис. 1. Така цивілізація повинна гармонійно поєднати іï функціональні підсистеми:

- політико-правові (правова держава і громадянське суспільство);

- економічні (оптимальне поєднання загальнодержавної і муніципальної, корпоративної і приватної форм власності, змішана економіка, засоби стимулювання суспільно корисної діяльності);

- екологічні (коеволюція суспільства і природи, людини і біосфери, відновлення гармонії між ними, ефективне використання природних ресурсів, цілеспрямоване екологічне виховання).

На Саміті ООН зі сталого розвитку 25 вересня 2015 р. 193 держави світу (зокрема делегація України на чолі з Президентом) одностайно прийняли новий "Порядок денний для сталого розвитку до 2030 р.", а 5 листопада 2015 р. під час 38-ї сесії Генеральної конференції ЮНЕСКО світова освітня спільнота прийняла "Рамки дій "Освіта-2030"', де зазначено, що "освіта $€$ серцевиною "Порядку денного для сталого розвитку до 2030 р." і істотною для успіху досягнення всіх цілей сталого розвитку". Опираючись на ці документи та власні напрацювання, ми поглибили розуміння сутності сталого (гармонійного, збалансованого) розвитку як процесу позитивних змін у житті людських спільнот на мікро-, макро- та мегарівнях, накопичення людського і соціального, раціонального використання і відновлення природного капіталів, в яких соціальна, економічна та екологічна діяльність, напрям інвестицій, інновацій та інституційних змін узгоджені між собою, тобто мають системний характер, і синергічно зміцнюють нинішній і майбутній потенціал людського розвитку.

Суспільство стане справді изивілізованим тоді, коли всі сфери його діяльності (демографічна, економічна, інформаційно-духовна, технологічна, комунікаційна, екологічна) гармонійно поєднаються. Ми вважаємо поняття "культура" і "цивілізація" вихідними для розвитку. Історія людства має єдину основу - духовну, яка реалізується в культурі. Вона починається зі своєрідного осьового моменту - формування світових релігій і філософій. Складаються духовні центри людства, які єднають різні народи і регіони. Дух забезпечує иілісність цивілізаціі. Цивілізачія створює засоби для формування, передачі в часі і розвитку культури.

\section{ПРИРОДНЕ СЕРЕДОВИЩЕ}

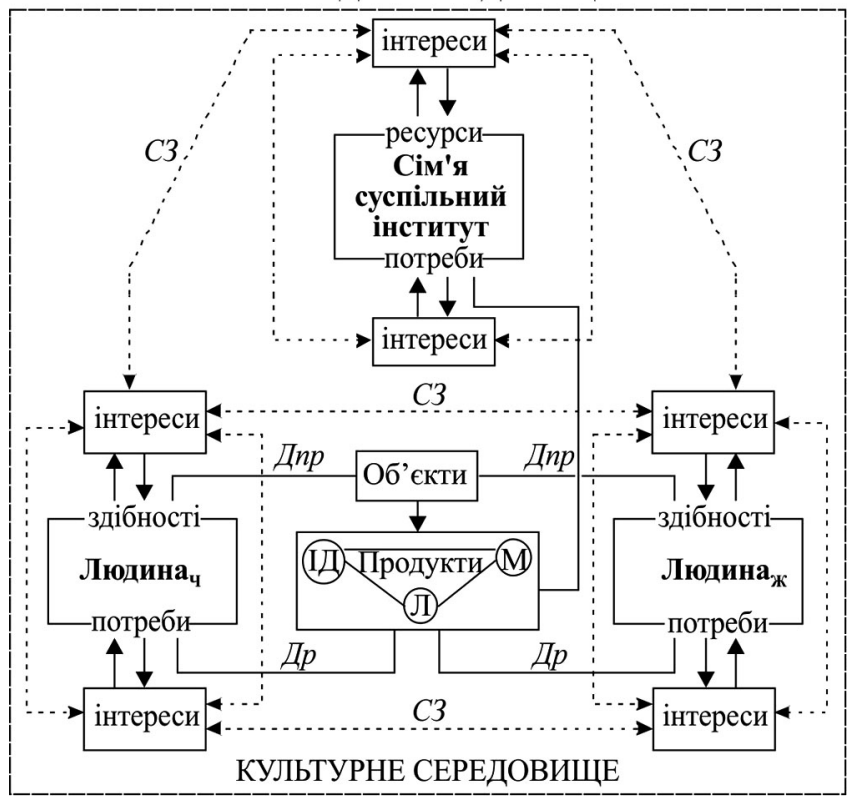

Рис. 2. Сім'я як суб'єкт формування і накопичення людського капіталу: Д - діяльність (пр) продуктивна і (p) репродуктивна; С3 - суспільні зв'язки; ІД - інформаційно-духовні продукти; М - матеріальні продукти; Л - люди; Ч - чоловік; Ж - жінка

Культура є духовною та символічною, а циивілізація - об'єктивованою та матеріальною. Цивілізація деградує, якщо виходить з-під контролю культури. У центрі нашого розуміння світоглядної концепції сталого розвитку стоїть людина, проблеми ї̈ гармонійного розвитку, який відбувається на фундаментальних засадах цілісного гуманізму й екологізму, що передбачають олюднення людини, піднесення якості її духу на рівень "відповідальності перед Богом, власною совістю, попередніми, нинішніми та прийдешніми поколіннями" (Конституція України), за своє життя і життя людських спільнот, збереження всього його розмаїття на Землі.

1. Міждисциплінарний підхід до дослідження проблем формування людського капіталу сталого розвитку та освітньої діяльності університетів. Людина як економічний суб'єкт та її людський капітал. 
Сім'я як суб'скт виникнення i формування людського капіталу. Сім'я - універсальна суспільна структура, "молекула" суспільного організму, що виникає на основі біосоціальної взаємодії людей протилежних статей: мужчини і жінки. Модель сім'ї як "двоатомної молекули" суспільства (рис. 2) дає змогу зафіксувати основні принципи ії будови і функціонування та пояснити механізм біосоціокультурної спадковості розвитку народів та людства загалом.

Унікальність сім'ї як соціальної групи полягає в тому, що саме іiї функціонування забезпечує не тільки сучасне існування, а й розвиток суспільства в часі. Окрема людина біологічно смертна, але людство на Землі безсмертне до того часу, поки існують сім'ї, які створюють головні продукти людської діяльності - самих людей. Вивчення "анатомії" i "фізіології" національної економіки потребує "вторгнення" економіста у сферу людського життя, яка, як і раніше, переважно, перебуває за межами інтересів економічної науки.

Складність економічного аналізу сім'ї зумовлена тим, що в ній тісно переплітаються і взаємопроникають усі сторони людської діяльності: соціально-демографічна, інформаційно-духовна, економічна, екологічна, комунікаційна, технічна, регулятивна. Саме системний підхід до людини і суспільства допомагає подолати цю складність, наблизити "суху" економічну теорію до нашого повсякденного життя. Суспільство сталого розвитку потребує людського капіталу нової якості. 3 огляду на проблему людського капіталу, економіст-теоретик розглядає освіту й наука. Oсвіта $i$ професійна підготовка $є$ найважливішими вкладеннями в людський капітал. Вони тісно пов'язані з розвитком науки, яка на шляху до сталого розвитку має докорінно змінити свої пріоритети. Сучасний некерований науково-технічний прогрес, зорієнтований насамперед на зміцнення військово-технічної та економічної могутності держав, веде до невпинного поглиблення екологічної кризи, створюючи реальну загрозу виживанню людства. Заради збереження життя на Землі науково-технічний прогрес має отримати гуманістично-екологічне спрямування. Такий розвиток науки та інформаційних технологій повинні усунути суперечності між розвитком цивілізації і збереженням її основи - природного довкілля.

2. Економічний дискурс освіти для сталого розвитку. Домінуюча технократична парадигма освіти трактує підготовку студента до майбутньої професійної діяльності як навчання для засвоєння знань та формування навичок і вмінь, навченості, а не "учіння" чи компетентності майбутніх фахівців, що, зрештою, і спричинило колосальний розрив між технічною, інструментальною здатністю до прийняття рішень і всебічне осмислення їхніх наслідків. Тому у філософсько-історичному контексті освіта має надати фахівцю не лише знання, але й ініціювати процеси формування нових норм відповідальної професійної і побутової поведінки, цілісного світогляду і світосприйняття. Має відбутися переоцінка суспільних та особистих цінностей, щоб сформувалось розуміння того, що якість довкілля є базовою складовою благополуччя кожного, а сучасний спосіб життя загрожує втратою стану довкілля, який необхідний для людини як біологічної істоти, процвітання життя на Землі та його багатоманіття.
У сучасному дискурсі освіти для сталого розвитку велика роль відводиться підходу до організації навчання (whole school approach), який сприяє підвищенню його дієвості. Зміст навчання має бути підкріплений і продовжений корпоративною культурою університетів, екологічним менеджментом "зелених студентських містечок", відкритістю для еко-інновацій, методами навчання, які формують у студентів навички вирішення проблем на засадах сталого розвитку. Університети повинні не просто доносити зміст проблематики сталого розвитку і повчати, але й вони мають діяти відповідним чином, трансформуючи їх функціонування, управління, політику й адміністрування. Тож освіта для сталого розвитку виступає як каталізатор змін в освіті і зазвичай знаходиться в центрі креативної діяльності всіх учасників процесу навчання.

У 2018 р. НЛТУ України вперше увійшов в міжнародний рейтинг UI Green Metric World University Ranking і посів I місце 3-поміж українських вишів. А серед освітніх установ світу НЛТУ України посідає 197 позицію. У цьому році в рейтингуванні брало участь 719 університетів із 81 країни. 19 грудня 2018 р. Університет Індонезії (UI) опублікував результати UI GreenMetric World University Rankings 2018. Рейтинг оголосили на інтерфейсі Balai Sidang UI Ректор університету Індонезії, nрофесор Dr. Ir. Muhammad Anis, M.Met і голова UI GreenMetric, професорм Prof. Dr. Riri Fitri Sari, M.Sc., MM. У церемонії також взяли участь представники Міністерства навколишнього середовища і лісового господарства та Міністерства досліджень та вищої освіти Республіки Індонезія. Green Metric World University Ranking складається Університетом Індонезії з 2010 р. Серед експертів рейтингу - фахівці, які беруть участь в інших престижних міжнародних рейтингах Webometrics, HEEACT, Educational Policy Canada.

Для розуміння сутності сталого розвитку необхідна різнопланова компетентність, в основі якої є готовність думати, діяти і брати відповідальність на основі холістичного розуміння передумов життя на Землі у глобальній перспективі. Вона охоплює готовність постійно навчатися від інших і співпрацювати, долаючи дисциплінарні та професійні обмеження, мислити, критично аналізувати і вирішувати проблеми, шукаючи можливості та долаючи обмеження у професійних функціях. Важливою $є$ здатність до комплексного мислення і використання експертів із різних галузей. Лідери повинні створювати ентузіазм і креативно мислити.

Постнекласична наука, яка досліджує системи, використовуючи міждисциплінарні синергетичні підходи, $\epsilon$ тим методологічним підгрунтям, яке дає змогу піднятися на вищий рівень у дослідженні еволюціонуючих систем, долаючи обмеженість технократичної науки та освіти (Tunytsia et al., 2016). Тому в освіті для сталого розвитку важливими дисциплінами є теорія складних систем і системної динаміки.

Новітня системно-синергетична методологія наукового пізнання здатна подолати однобокість домінуючої світоглядної парадигми суспільно-економічного розвитку, здійснити гуманістичний синтез сучасних економічних доктрин на основі екологічного імперативу (Zahvoiska, 2011). Ми обгрунтували, що основними причинами відсутності прогресу у використанні системно-синергетичної методології в наукових дослідженнях, а також грубого матеріалістичного трактуван- 
ня взаємозв'язку "людина - природа - суспільство економіка" є:

- по-перше, ігнорування сучасної світоглядної позиції в розумінні людини, природи, суспільства та економіки, заснованої на поєднанні наукового і релігійного підходів;

- nо-друге, недостатне володіння системно-синергетичнюю методологією наукового пізнання, що веде до ототожнювання базових системних понять (система, елемент, зв'язки, структура, інформація, управління, організація, розвиток та ін.);

- по-трете, неврахування особливостей таких надскладних систем, як людина і суспільство та їхня діяльність, яка здійснюється для задоволення необмежених потреб в умовах обмежених природних ресурсів і обмежених можливостей природного життєвого довкілля планети.

Сьогодні важливою прикметною тенденцією розвитку системи освіти $є$ екологізація освіти, зокрема освіти для сталого розвитку. Екологізація освіти - це процес насичення навчальних програм підготовки фахівців усіх напрямів екологічними аспектами з метою формування еколого-економічного способу мислення, замість однобокого традиційного економічного мислення, а освіту для сталого розвитку розглядають як розширення процесів екологізації освіти 3 урахуванням соціального виміру суспільного розвитку, яка формує глибинне, цілісне розуміння взаємозумовленості та взаємозалежності економічних, екологічних і соціальних систем. Освіту визнано найбільш ефективним інструментом імплементації стратегії сталого розвитку.

Результати дослідження засвідчили ефективність стратегії екологізації освітнього процесу, запровадженої в НЛТУ України. Незалежно від профілю спеціальності, студенти бережливо ставляться до природи, розуміння іiі живої сутності та необхідності дотримуватися норм екологічно-орієнтованої поведінки. Водночас міра усвідомлення студентами актуальності екологічних проблем залежить від специфіки їхньої професійної підготовки (наскільки їхня майбутня професійна діяльність включена у систему "людина - природа"): найвищі показники зрілості екологічної свідомості виявлено у магістрантів спеціальності "Економіка довкілля і природних ресурсів" (2015).

Для досягнення цілей сталого розвитку університети повинні відмовитися від вузької спеціалізації в науці та підготовці фахівців із вищою освітою. Фахівець для сталого розвитку, незалежно від того, яку спеціальність він здобув внаслідок навчання у ВН3, - це має бути фахівець із сформованою екологічною компетентністю, тобто здатністю гармонійно взаємодіяти 3 довкіллям і соціумом у всіх сферах своєї життєдіяльності. Обгрунтовуючи потребу розглядати екологічну компетентність фахівця 3 вищою освітою як важливу складову його професійної компетентності, вважаємо, що в рекомендованому МОН України переліку загальних компетентностей, які враховують під час розроблення нових стандартів вищої освіти, ця компетентність має бути пріоритетною.

Вимогою часу $є$ те, щоб навчальні заклади не лише відповідали запитам сучасності, але й ставали динамічними інституціями, своєрідними "лабораторіями сочіальних екоінновацій", що завжди на крок попереду будь-яких суспільних змін. Саме тому чимало країн за останні два десятиліття інтегрували принципи сталості в національні стратегії розвитку. Ці впливи не оминули й стратегії розвитку освіти (Solovii et al., 2014). Однак, перехід на принципи сталого розвитку значною мірою відбувається саме завдяки змінам у системі освіти і підготовці фахівців, які володіють новими кваліфікаціями (т. зв. green skills).

\section{3. Передумови становлення нової якості людсь-} кого капіталу фахівців

Системна концепція виховання і самовдосконалення студентів. Проблема сталого розвитку - це передусім проблема людини у всіх їі вимірах. Тому виховання та освіта разом з наукою становлять блок гуманітарного забезпечення переходу до суспільства сталого розвитку для формування людини 3 новою мораллю, новим світоглядом, психологічною настановою на сприйняття людиною екологічного імперативу та цінностей суспільства як особистих цінностей.

Сучасний університет $\epsilon$ соціальним інститутом, в якому акумулюється людський капітал вищої якості. Щоб виконувати це високе суспільне призначення, він сам має придбати нову якість, подолати кризові явища в своєму функціонуванні та розвитку. Насамперед це торкається навчально-виховного прочесу, в якому, з одного боку, не подолані вади радянської педагогіки вищої школи, $з$ другого - некритично сприймається досвід західних університетів. Важливим чинником перебудови системи освіти і науки в Україні на засадах сталого розвитку є вдосконалення інституційних засад виховної діяльності вищої школи. Виховання студентів складний і багатогранний процес формування особистості фахівців, створення оптимальних умов для їх гармонійного розвитку.

"Закон України про вищу освіту" визначив ключові завдання вищого навчального закладу. Концепція національного виховання студентської молоді (Рішення Колегії МОН України (протокол №7/2-4 від 25.06.09 року) конкретизує головні з них: суть національної ідеї, нащіонального характеру, національного виховання студентів. Глобальний простір, у який інтегрується фахівець, передбачає засвоєння надбань культури різних народів за умови збереження української національної ідентичності. Національне виховання має стати фундаментом становлення світогляду студентів, на якому формуються їхні фахові знання, компетентність і професійна відповідальність.

Ключовими завданнями виховання студентів є: формування національної свідомості, гідності громадянина, виховання поваги й любові до рідної землі й українських традицій; підготовка свідомої інтелігенції України, збереження інтелектуального генофонду нації; вироблення чіткої громадянської позиції, прищеплення молодим людям віри у верховенство закону, який є єдиною гарантією свободи; підняття престижу української мови в академічному середовищі, забезпечення і розвиток українськомовного освітнього простору, формування в суспільній свідомості переваг здорового способу життя, культу соціально активної, фізично здорової та духовно багатої особистості, створення необхідних умов для ефективного розвитку студентського самоврядування, виявлення його потенційних лідерів та організаторів, забезпечення високого рівня професійності та вихованості, сприяння розвитку індивідуальних здібностей, таланту та самореалізації; плекання поваги до своєї alma mater, дотримання і розвиток демократичних та ака- 
демічних традицій (http://osvita.ua/legislation/Vishya_osvita/4310/).

Куратор академічної групи, адаптаційний курс i студентське самоврядування. Багаторічний досвід організації навчально-виховного прочесу в НЛТУ України переконує, що в системі суб'єктів національного виховання науково-педагогічних працівників і студентів, особливу роль відіграють виховник (куратор) академічної групи і органи студентського самоврядування, Вони, як і кураторство, сягають своїм корінням ще часів виникнення перших університетів. Вже тоді найбільш здібні студенти залучалися до виконання окремих адміністративних функцій, а також до викладання як помічники професорів. Недаремно університети вважаються своєрідною моделлю громадянського суспільства, яка передувала сучасному типу європейської цивілізації. У нинішніх університетах студенти беруть активну участь у забезпеченні якості освіти та управлінні, яке здійснюється зокрема через органи студентського самоврядування. Таку колективну, солідарну участь потрібно розглядати не просто як додаткову гарантію адекватності освітніх послуг вимогам їх реципієнтів (студентів і роботодавців), а й як істотний чинник соціалізації молоді, зростання її політичної та правової культури й суспільної активності, який дає змогу студентам на практиці ознайомитися $з$ функціонуванням навчального закладу (через участь у підготовці та прийнятті певних рішень) і системою представницької демократії (на прикладі виборних органів студентського самоврядування). Натомість в Україні функціонування інституцій студентського самоврядування ще недостатньо ефективне як для вирішення власне студентських проблем, так і щодо оптимізації навчального процесу. Однією 3 найістотніших перешкод залишається майже повна залежність студентських самоврядних інституцій від адміністрації ВНЗ (студентських рад професійних і громадських товариств, університетських 3МІ тощо). 3 огляду на потребу забезпечення поступального розвитку вищої освіти в Україні, проблема слабкості інституту студентського самоврядування потребує негайного вирішення (Див. комюніке Всесвітньої конференції "Нова динаміка вищої освіти і науки для соціальної зміни і розвитку" (ЮНЕСКО, Париж, 5-8 липня 2009 р.).

Висновки. Обгрунтовано роль сучасного університету як суспільного інституту, в якому накопичується основний ресурс майбутнього суспільства - людський капітал вищої якості, формуються його стратегії, програми і технології. Визначено місце університетів у Стратегії ЄЕК ООН для освіти в інтересах сталого розвитку. Особливу увагу звернено на досвід Національного лісотехнічного університету України - як репрезентанта формування і втілення в життя моделі изілісної концепиії екологізації вищої професійної освіти.

\section{References}

Becker, G. S. (1993). Human Capital. A Theoretical and Empirical Analysis, with Special Reference to Education. Chicago: The Univercity of Chicago Press, $390 \mathrm{p}$.

Education. (2019). Greening of Education: Ukraines Contribution. Retrieved from: https://sustainabledevelopment.un.org/partnership/?p=77

Ekolohizatsiia. (2015). Rishennia Kolehii MON Ukrainy vid 27.11.2015 r. "Pro ekolohizatsiiu vyshchoi osvity z metoiu pidhotovky fakhivtsiv dlia staloho rozvytku". Retrieved from: http://www.lp.edu.ua/opportunities/2017/mizhnarodna-naukovo- praktychna-konferenciya-ekologizaciya-osvity-yak-chynnyk Ukrainian].

Frantsysk. (2015). "Laudato si" - "Slaven bud": "Pikluvannia pro nash spilnyi dim". Korotkyi vyklad novoi entsykliky Papy Frantsyska. Ukrainskyi pereklad zdiisneno na zamovlennia Biuro UHKTs z pytan ekolohii. Retrieved from: https://ecoburougcc.org.ua/index.php/ekologichni-dokumenti-tserkvi/2534-laudato-si-slaven-

bud-korotkij-viklad-novoyi-entsikliki-papi-frantsiska. [In Ukrainian].

Havrylyshyn, B. (1993). Dorohovkazy v maibutnie: do efektyvnishykh suspilstv. Dopovid Rymskomu klubu. (Trans. from English). Kyiv: Osnovy, 238 p. [In Ukrainian].

Intehratsiia. (2016). Tematychnyi vypusk "Yevropeiska intehratsiia vyshchoi osvity Ukrainy v konteksti Bolonskoho protsesu", 4 (dodatok 2), (pp. 52-56). [In Ukrainian].

Konstytutsiia Ukrainy. (2003). Pryiniata na piatii sesii Verkhovnoi Rady Ukrainy 28 chervnia 1996 roku. Kharkiv: Folio, 47 p. [In Ukrainian].

Kvit, S. (2013). Social responsibility of Ukrainian university. Speech at 2013 Annual Conference of Canadian Bureau for International Educationin in Vancouver Education for a Better World: Our Global Social Responsibility, November. Retrieved from: http://kvit.ukma.kiev.ua/2013/12/social-responsibility-ofukrainianuniversities/\#more-1512.

Pedahohika. (2019). Studentske samovriaduvannia. Pedahohika vyshchoi shkoly Retrieved from: http://pidruchniki.com/70199/pedagogika/studentske samovryaduvannya. [In Ukrainian].

Ragazzi, M., \& Ghidini, F. (2017). Environmental sustainability of universities: critical analysis of a green ranking. Energy Procedia, 119, 111-120.

Solovii, I. P., Henyk, Ya. V., \& Solovii, V. I. (2014). Upravlinnia profesiinym navchalnym zakladom na zasadakh staloho rozvytku. Ivano-Frankivsk: Lileia-NV, 162 p. [In Ukrainian].

Thomashow, M. (2014). The Nine Elements of a Sustainable Campus. MIT Press.

Tunytsia, Yu. Yu. (Ed.), Zahvoiska, L. D., \& Maksymiv, L. I. (Reds). (2015). Ekonomika dovkillia i pryrodnykh resursiv. Informatsiinyi paket. Lviv: Afisha, 372 p. [In Ukrainian].

Tunytsia, Yu. Yu. (Ed.). (2017). Teoretyko-metodolohichni zasady ekolohizatsii osvity yak chynnyka formuvannia liudskoho kapitalu dlia staloho rozvytku. Zvit z naukovo-doslidnoi roboty. Lviv, 223 p. [In Ukrainian].

Tunytsia, Yu. Yu., Adamovskyi, M. H., Borys, M. M., Kraievskyi, S. N., \& Mahazynshchykova, I. P. (2015). Ekolohizatsiia osvity yak kliuchovyi faktor pidhotovky fakhivtsiv dlia staloho rozvytku. Scientific Bulletin of UNFU, 10, 348-356. [In Ukrainian].

Tunytsia, Yu. Yu., Mahazynshchykova, I. P., \& Adamovskyi, M. H. (2017). Sotsialna vidpovidalnist universytetu za dosiahnennia tsilei staloho rozvytku. Vyshcha osvita Ukrainy. [In Ukrainian].

Tunytsia, Yu. Yu., Zahvoiska, L. D., \& Adamovskyi, O. M. (2016). Ekonomichnyi dyskurs osvity dlia staloho rozvytku. Higher school, 4(74), 7-27. Retrieved from: http://ieem.nltu.edu.ua/images/docs/2016 vyshchaschool.pdf. [In Ukrainian].

von Weizsaecker, E., Wijkman, A. (2018). Come On! Capitalism, Short-termism, Population and the Destruction of the Planet. Springer, $220 \mathrm{p}$

Zahvoiska, L. D. (2011). Filosofsko-ekonomichnyi dyskurs problemy "Liudyna-Pryroda". In Ye. V. Khlobystov (Ed.), Stalyi rozvytok ta ekolohichna bezpeka: teoriia, metodolohiia, praktyka, (pp. 12-41). DU "IEPSR NAN Ukrainy", IPREED NAN Ukrainy, SumDU, NDI SRP. Simferopol: VD "ARIAL". Retrieved from: http://ndisrp.ucoz.ua/ ld/0/2 monographiya t1.pdf. [In Ukrainian].

Zasady. (2017). Zvit z naukovo-doslidnoi roboty: "Teoretyko-metodolohichni zasady ekolohizatsii osvity yak chynnyka formuvannia liudskoho kapitalu dlia staloho rozvytku". Lviv, 223 p. [In Ukrainian].

Zelenyi. (2018). NLTU - pershyi sered "Zelenykh universytetiv" Ukrainy. Subota, 22 hrudnia 2018. Retrieved from: https://nltu.edu.ua/index.php/component/k2/item/151-nltu-pershyysered-zelenykh-universytetiv-ukrainy/151-nltu-pershyy-sered-zelenykh-universytetiv-ukrainy. [In Ukrainian]. 


\section{SUSTAINABLE UNIVERSITY: THE MODEL OF SYSTEMIC INTEGRATION OF SUSTAINABILITY PRICIPLES IN ALL SPHERES OF ACTIVITY}

The worldview and general methodological preconditions for greening educational activity of universities on the basis of the concept of human capital for sustainable development are analyzed using retrospective and content analysis. The purpose of greening educational activity is to educate new generation with the holistic vision of the real world, the essential feeling of responsibility and active social behaviour as a pioneer of sustainability transformations. The article presents the functional model of sustainable development civilization, which harmoniously combines the political-legal, economic and ecological subsystems. The second model presented in the article is the model of a family as the subject of the formation and accumulation of human capital. These two models substantiate the role of human capital in achieving sustainable development goals. The economic discourse of education for sustainable development and modern tendencies of education systems development are proposed. The methodological and didactic aspects of greening educational activity of universities on the basis of the competence approach are discussed. The theoretical and methodological features of greening different elements of the system for training professionals on the basis of the concept of human capital for sustainable development are proposed. The concept of social responsibility of the university has been analysed. The place of universities in the UNECE Strategy implementation is designated. The world experiences of the transition to university sustainability have been studied. The role of the whole school approach in shaping the modern education discourse for sustainable development is substantiated. This approach determines the efficiency of education, and induces changes in professional and everyday behaviour as well. The preconditions for systemic and holistic integration of the sustainability principles into all spheres of the university activity are determined. Particular attention is paid to the experience of Ukrainian National Forestry University as the representative of the formation and implementation of the model of the coherent concept of higher education greening.

Keywords: education for sustainable development; greening of education; human capital; competence approach; sustainable university. 